\title{
Penilaian formatif bahan pengajaran dan pembelajaran Bahasa Melayu sebagai Bahasa Asing di Thailand
}

\author{
Formative evaluation on the teaching and learning materials of Malay Language \\ as a Foreign Language in Thailand \\ Kusom Yamirudeng \\ kusom@yahoo.com \\ Universiti Thaksin, Songkhla, Thailand \\ Zulkifli Osman \\ zulkifli@fbk.upsi.edu.my \\ Universiti Pendidikan Sultan Idris, Tanjung Malim, Perak, Malaysia \\ DOI: https://doi.org/10.37134/pendeta.vol10.7.2019
}

\begin{abstract}
ABSTRAK
Kajian ini bertujuan melaporkan proses penilaian formatif bahan pengajaran dan pembelajaran Bahasa Melayu sebagai bahasa asing di Thailand berdasarkan model penilaian formatif Tessmer. Kajian ini melibatkan tiga tahap penilaian, iaitu penilaian pakar, maklum balas daripada pensyarah dan pelajar, kumpulan kecil atau rintis, dan kajian lapangan. Tiga pihak terlibat sebagai responden dalam kajian ini, iaitu pakar bidang, pensyarah, dan pelajar. Borang penilaian bahan, komen bersemuka, dokumen pelajar dan bahan yang dibangunkan digunakan sebagai instrumen kajian. Dapatan penilaian pakar, pensyarah dan pelajar menunjukkan bahawa bahan ini perlu disesuaikan dan diperbaiki khususnya dari aspek kandungan, bahan pengajaran dan pedagogi. Dapatan penilaian kumpulan kecil pula mendapati bahawa aspek kandungan, bahan pengajaran, motivasi, pedagogi, kemahiran bahasa dan penilaian sesuai dengan kemampuan pelajar. Dalam penilaian lapangan pula, didapati bahawa aspek penggunaan bahasa, kandungan, ilustrasi, bahasa dan aktiviti yang terdapat dalam bahan pengajaran dan pembelajaran ini dapat memberi kesan yang baik terhadap pelajar. Implikasi kajian menunjukkan bahawa bahan pengajaran dan pembelajaran bahasa yang dibangunkan perlu mengambil kira pandangan pelajar khususnya dari aspek kandungan, bahan pengajaran dan pedagogi.
\end{abstract}

Kata kunci: penilaian formatif, bahan pengajaran dan pembelajaran, pelajar asing (Thai)

\section{ABSTRACT}

This study aims to report the process of 'formative assessment' on the teaching and learning of Malay as a foreign language in Thailand based on the advanced model by Tessmer. It consists of three evaluation stages: 1) expert assessment, 2) feed-back from lecturers and students in small or pilot test groups, and 3) field studies obtained from the participation of field experts, lecturers, and students. Evaluation forms, interviews, student documentation, and developed materials are employed as the research instruments. The findings from the experts, lecturers, and students indicate that these materials need to be adapted and improved, especially from the expects of content, teaching materials, and pedagogy. On the other hand, the small group assessments showed that some aspects of content, teaching materials, motivation, pedagogy, language skills, and assessment are suitable fit the students' abilities. The field study has revealed that language use, content, illustration, language, and activities which are the focus of these materials can give a positive impact on students. The implication of this study proves that the development of teaching and learning materials needs to take into consideration of students' views of the contents, teaching materials, and pedagogy.

Keywords: formative assessment, teaching and learning materials, foreign students (Thai) 


\section{PENDAHULUAN}

Bahasa Melayu telah diajarkan di selatan Thailand sejak lama dahulu. Pada tahun 1947, masyarakat Melayu di selatan Thailand membuat rayuan kepada kerajaan Thai supaya mengiktiraf kebudayaan Melayu, termasuk mengamalkan cara hidup Islam. Di samping itu, terdapat perkara yang berkaitan dengan bahasa dan bangsa Melayu, iaitu memasukkan mata pelajaran Bahasa Melayu dengan menggunakan tulisan Jawi di setiap sekolah rendah kerajaan Thai (Ahmad Omar Chapakia, 2002). Pada tahun 1958 pula pengajaran Bahasa Melayu diajar melalui tulisan Rumi atau Jawi, tetapi semakin diketepikan dan akhirnya telah dihentikan dan tidak lagi dimasukkan ke dalam sistem pendidikan kerajaan (Worawit Baru, 1999).

Perkembangan pengajaran bahasa Melayu di selatan Thailand tidak terlepas daripada situasi politik di Thailand. Pada suatu ketika (1950-an), kerajaan pernah membenarkan pengajaran bahasa Melayu di sekolah-sekolah kerajaan dengan membawa masuk guru-guru Melayu dari Singapura dan Malaysia. Namun pada ketika yang lain, pengajaran bahasa Melayu tidak lagi diajarkan di sekolah-sekolah kerajaan. Keadaan ini menyebabkan guru-guru Bahasa Melayu terpaksa mengajarkan Bahasa Melayu di rumah masing-masing (Islyas Mahyudin, 2008). Namun demikian, pengajaran Bahasa Melayu masih tetap dilaksanakan di pondok dan di sekolah agama atau dikenali sebagai sekolah agama swasta pada zaman sekarang. Di sekolah agama swasta, mata pelajaran Bahasa Melayu diwajibkan bagi semua pelajar.

Di Thailand, pengajaran Bahasa Melayu untuk penutur Thai secara rasminya telah dilaksanakan dalam sistem pendidikan kebangsaan sejak abad ke-19 (Paitoon M. Chaiyanara, 2001). Dewasa ini, mata pelajaran Bahasa Melayu telah dimasukkan dalam sistem pendidikan kerajaan dan diajarkan sebagai bahasa asing di sekolah-sekolah dan di pusat-pusat pengajian tinggi.

Peranan bahasa Melayu di Thailand dapat dilihat dari dua aspek, iaitu peranan sosiolinguistik dan sebagai wahana pendidikan. Dari aspek sosiolinguistik, bahasa Melayu berperanan sebagai bahasa pengantar dalam masyarakat Melayu dan merupakan bahasa ibunda dalam kalangan penduduk di selatan Thailand.

Dari aspek pendidikan, bahasa Thai merupakan bahasa kebangsaan atau bahasa rasmi. Bahasa Thai juga berperanan sebagai bahasa ibunda atau bahasa pengantar bagi penduduk Thai, manakala bahasa Inggeris diajarkan sebagai bahasa kedua. Bahasa-bahasa lain dalam pendidikan pula diajarkan sebagai bahasa asing. Kursus-kursus bahasa asing ditawarkan kepada para pelajar di sekolah dan pusat pengajian tinggi di Thailand, iaitu bahasa Melayu, Cina, Jepun, Korea, Jerman, Perancis, dan lain-lain. Oleh sebab itu, bahasa Melayu diajarkan sebagai bahasa asing. Walaupun bahasa Melayu dianggap sebagai bahasa ibunda bagi masyarakat Melayu di selatan Thai tetapi dari aspek pendidikan bahasa secara rasmi, bahasa Thai dipelajari sebelum bahasa Melayu.

\section{PERNYATAAN MASALAH}

Mengikut sejarah, pendidikan bahasa Melayu di Thailand sudah diajarkan sejak peringkat sekolah rendah hingga universiti. Hal ini bermaksud bahasa Melayu itu memainkan peranan yang penting dalam sistem pendidikan di negara ini, selaras dengan keperluan pasaran. Malahan, bahasa Melayu semakin meningkat dan diajar sebagai bahasa asing (B2) di peringkat universiti.

Oleh itu, proses pengajaran dan pembelajaran (PdP) bahasa Melayu perlu disemak semula agar sesuai dengan tujuannya. Menurut Asmah $\mathrm{Hj}$. Omar (2003), bahasa kedua dipelajari berdasarkan dua fungsi, iaitu fungsi integratif dan instrumental. Fungsi integratif melibatkan pembelajaran bahasa yang didorong oleh keinginan untuk berkomunikasi dengan masyarakat penutur bahasa sasaran. Fungsi instrumental pula didorong oleh tujuan mempelajari bahasa itu sendiri seperti memperoleh pekerjaan, mobiliti sosial dan sebagainya. Dalam konteks di selatan Thailand, bahasa Melayu perlu diajar kerana bahasa ini memenuhi kedua-dua keperluan bahasa tersebut.

Di samping itu, Awang Sariyan (2012) menyatakan bahawa dalam proses PdP bahasa, lima aspek utama perlu diberi perhatian, iaitu (i) pelajar, (ii) pengajar, (iii) kurikulum dan kaedah, (iv) sumber atau 
bahan, dan (v) pengujian dan penilaian. Oleh sebab itu, berdasarkan beberapa pendapat tokoh tersebut, boleh dirumuskan bahawa perkara asas dan penting dalam sesuatu PdP bahasa asing ialah pelajar, pengajar, kurikulum, bahan pengajaran, penilaian dan sosiobudaya. Oleh itu, kajian ini mengetengahkan bahan PdP yang boleh digunakan oleh pelajar yang mempelajari bahasa Melayu sebagai bahasa asing di selatan Thailand.

Pembinaan bahan PdP ini penting kerana pelajar yang mempelajari bahasa Melayu sebagai B2 berhadapan dengan masalah kekangan bahan pengajaran dan pembelajaran yang sesuai untuk pelajar Thai. Pareedah Hayeeteh dan Suhaila Sama-ae (2011) menyatakan bahawa kekurangan bahan pengajaran dan pembelajaran bahasa Melayu juga menjadi salah satu penyebab kepada kelemahan penguasaan bahasa tersebut oleh pelajar-pelajar di universiti-universiti di selatan Thailand. Hal ini menunjukkan bahawa bahan bacaan di Thailand masih kurang dan tidak sesuai dengan konteks pelajar di Selatan Thailand. Oleh itu, pengkaji berhasrat membangunkan sebuah bahan PdP yang sesuai dengan latar belakang pelajar Thai supaya dapat mengurangkan beban dan membantu pelajar terhadap proses PdP bahasa Melayu di Thailand.

\section{OBJEKTIF KAJIAN}

Kajian ini bertujuan mendapatkan pandangan pakar, pensyarah dan pelajar bagi membangunkan bahan pengajaran dan pembelajaran bahasa Melayu sebagai bahasa asing di Universiti Thaksin, Thailand. Objektif khusus kajian ini adalah seperti berikut:

1. Mengenal pasti penilaian pakar dan pensyarah terhadap aspek kesesuaian bahan pengajaran dan pembelajaran Bahasa Melayu yang dibangunkan dalam fasa reka bentuk dan pembangunan.

2. Mengenal pasti penilaian pelajar terhadap bahan pengajaran dan pembelajaran Bahasa Melayu yang dibangunkan dalam fasa reka bentuk dan pembangunan.

3. Mengenal pasti penilaian pensyarah dan pelajar dalam fasa kajian rintis atau fasa kebolehlaksanaan.

4. Mengenal pasti penilaian dan pandangan pelajar terhadap bahan yang dibangunkan dalam fasa kajian lapangan.

\section{KEPENTINGAN KAJIAN}

Kajian ini dijalankan atas kepentingan yang berikut:

1. Pembangunan bahan ini memberi peluang kepada pelajar mengalami proses pengajaran bahasa secara kontekstual melalui aktiviti pembelajaran yang mementingkan suasana yang sebenar dan bahan pembelajaran yang interaktif, sesuai, dan menarik dengan keadaan sekeliling.

2. Pembangunan bahan ini dapat membantu para tenaga pengajar untuk mengajar mata pelajaran Bahasa Melayu dengan lebih berkesan melalui bahan-bahan pengajaran dan pembelajaran yang sesuai serta menarik dengan kebolehan minat pelajar. Tenaga pengajar juga dapat menjimatkan masa dalam proses menyediakan bahan bantu mengajar. Bahan ini boleh menjadi sumber rujukan dan panduan kepada guru. 
3. Pembangunan bahan PdP ini merupakan satu inovasi baharu dalam pendidikan bahasa Melayu di Thailand dan diharap dapat menarik minat pelajar untuk mempelajari Bahasa Melayu.

\section{SOROTAN LITERATUR}

\section{Penilaian Formatif}

Menurut Tessmer (1993), terdapat empat peringkat penilaian formatif iaitu penilaian pakar, penilaian satu dengan satu, penilaian kumpulan kecil, dan penilaian lapangan. Penilaian formatif dilaksanakan sepanjang proses pembangunan perisian/bahan, bertujuan untuk memastikan halangan-halangan yang tidak dijangka, perubahan dalam kehendak pengguna, masalah-masalah yang dihadapi oleh pengguna dalam menggunakan perisian/bahan dan sebagainya (Baharuddin et al., 2002). Penilaian ini dilaksanakan bagi menjamin pembangunan sesebuah perisian/bahan dapat memenuhi citarasa pengguna serta memenuhi objektif pembelajaran yang diingini.

Semasa pembangunan perisian/bahan, proses penilaian formatif sangat penting bagi mengenal pasti kekuatan dan kelemahan bahan yang sedang dibangunkan bagi memastikan proses penambahbaikan dapat dilaksanakan. Setiap peringkat dalam penilaian formatif mempunyai peranan tersendiri bagi memastikan perisian/bahan yang dibangunkan dapat dibaiki mutunya sebelum digunakan oleh pengguna.

Tessmer (1993) turut menyatakan bahawa penilaian formatif dijalankan bagi mengukur kekuatan dan kelemahan bahan yang dibangunkan sama ada dalam kajian rintis mahupun ketika dalam kajian lapangan. Dalam kata lain, melalui penilaian formatif, pengkaji juga dapat menentukan keberkesanan, kebolehlaksanaan serta kebolehgunaan bahan pengajaran yang dibangunkan oleh pelajar (Tessmer, 1995).

Model penilaian formatif Tessmer (1993) melibatkan empat fasa, iaitu fasa penilaian pakar, penilaian satu dengan satu, kumpulan kecil (rintis) dan kumpulan sebenar. Tiga pihak berkepentingan terlibat dalam penilaian ini, iaitu (1) pereka bentuk pengajaran, (2) kumpulan pakar, dan (3) pengguna (Tessmer, 1993).

Penilaian fasa ini bertujuan untuk menilai, mengembangkan dan meningkatkan kesahan dan kualiti bahan PdP. Dalam konteks kajian ini, pemilihan pakar dibuat berdasarkan pengetahuan dan pengalaman serta sumbangan mereka terhadap peningkatan proses pengajaran (Tessmer, 1995).

Fasa penilaian formatif melibatkan peringkat penilaian dalam membangunkan bahan PdP. Terdapat 3 fasa utama dalam penilaian sesuatu bahan pembelajaran. Antaranya ialah fasa penilaian reka bentuk bentuk dan pembangunan, fasa penilaian kumpulan kecil atau kajian rintis, dan fasa penilaian lapangan atau kajian sebenar (Tessmer, 1995). Menurut Tessmer, fasa penilaian pembangunan terdiri daripada dua proses, iaitu proses penilaian pakar, dan proses penilaian pensyarah dan pelajar. Mereka ini ialah pemegang taruh dalam pelaksanaan sesuatu bahan yang dibangunkan. Dalam proses penilaian ini, aspek yang dinilai ialah kesesuaian dan kebolehgunaan bahan. Menurut Richey dan Klien (2007) serta Dick, Carey dan Carey (2005), dan Morrison et al (2007), aspek kesesuaian dan kebolehgunaan bahan ialah meliputi perkara yang berikut, iaitu kandungan bahan, pedagogi dan reka bentuk bahan. Selaras dengan hal ini, Zulkifli Osman (2013a) turut menyatakan bahawa penilaian formatif dapat meningkatkan kualiti bahan PdP.

Proses penilaian bahan ini dilakukan secara serentak dan berterusan dan dapatannya saling melengkapi antara satu sama lain. Penilaian pakar dan pensyarah melibatkan penilaian kandungan, objektif, strategi pengajaran, dan kesesuaian bahan. Penilaian pensyarah melibatkan kesesuaian bahan dari aspek kandungan, bahan pengajaran dan pedagogi. Penilaian pelajar pula, menilai dalam tiga aspek, iaitu, (i) kejelasan arahan, kandungan, teknikal, dan bahan dan aktiviti, (ii) output terhadap pelajar, dan (iii) pendapat lain terhadap pembangunan bahan PdP.

Proses penilaian dalam kajian rintis pula melibatkan penilaian pelajar dan pensyarah terhadap kebolehlaksanaan bahan PdP bahasa. Pensyarah dan 20 orang pelajar Songkhla Rajabhat University terlibat dalam penilaian tahap ini. Penilaian pensyarah melibatkan enam aspek, iaitu kandungan, bahan pengajaran, 
pedagogi, kemahiran bahasa, motivasi dan penilaian. Penilaian pelajar pula, penilaian meliputi aspek-aspek yang berikut, iaitu aspek kandungan, bahan pengajaran, pedagogi, kemahiran bahasa dan motivasi.

Akhirnya, penilaian lapangan (kajian sebenar) melibatkan pensyarah dan 40 orang pelajar di Universiti Thaksin. Penilaian ini dijalankan selepas pelajar menggunakan bahan PdP. Penilaian pensyarah dinilai berdasarkan enam aspek, iaitu kandungan, bahan pengajaran, pedagogi, kemahiran bahasa, motivasi dan penilaian. Penilaian pelajar pula, penilaian meliputi aspek-aspek yang berikut, iaitu aspek kandungan, bahan pengajaran, pedagogi, kemahiran bahasa dan motivasi. Rajah di bawah menunjukkan proses penilaian formatif Tessmer yang digunakan dalam kajian ini.

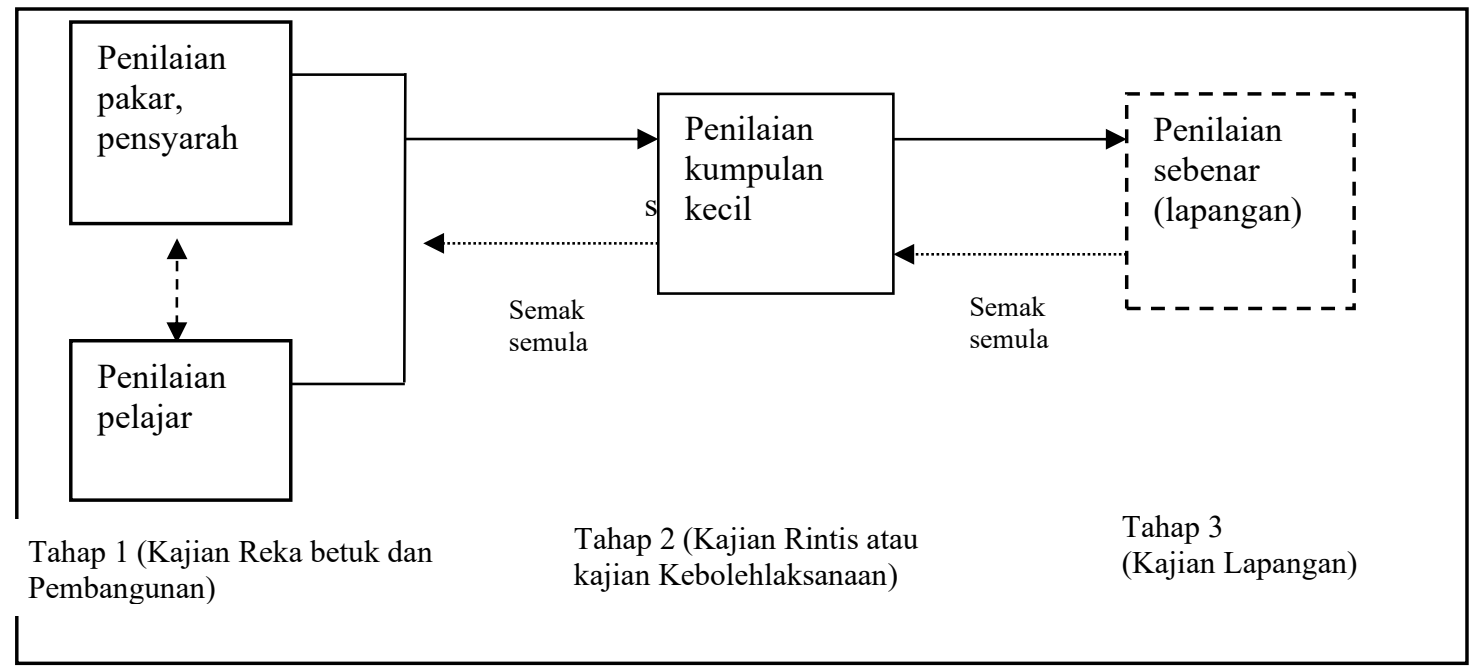

Rajah 2. Proses penilaian formatif bahan pengajaran dan pembelajaran Bahasa Melayu sebagai bahasa asing di Thailand (diadaptasi dari Tessmer, 1995)

\section{Bahan Pengajaran dan Pembelajaran Bahasa Melayu sebagai Bahasa Asing}

Kini, bahasa asing memainkan peranan yang penting dalam dunia pendidikan kerana individu yang boleh menguasi bahasa asing akan mendapat peluang yang lebih berbanding dengan individu lain. Oleh sebab itu, universiti di Thailand menetapkan prasyarat kepada semua pelajar wajib mendaftar kursus bahasa asing. Bahasa Melayu juga tergolong dalam kursus bahasa asing yang dipilih oleh pelajar. Bertitik tolak daripada ini, bahasa Melayu diajarkan sebagai bahasa asing di beberapa buah universiti di Thailand. Tambahan pula, bahasa Melayu mempunyai ramai penuturnya di negara-negara Asean, khususnya Indonesia, Malaysia, Brunei, Singapura, dan Thailand. Dalam menampung keperluan tersebut, penyediaan bahan pengajaran dan pembelajaran yang mencukupi sangat diperlukan kerana bahan PdP bahasa, khususnya yang sesuai dengan latar belakang pelajar merupakan faktor yang penting dalam proses PdP bahasa Melayu sebagai bahasa asing Asmah Hj. Omar (2003).

\section{METODOLOGI}

\section{Reka Bentuk Kajian}

Reka bentuk kajian ini ialah kajian reka bentuk dan pembangunan. Tujuan kajian ini ialah membangunkan dan menilai bahan PdP bahasa Melayu untuk kursus Bahasa Melayu berdasarkan pendekatan CLI. Kajian ini dibangunkan berdasarkan model kajian reka bentuk dan pembangunan Richey dan Klien (2007), dan Zulkifli Osman (2012 \& 2013b). Model ini digunakan kerana reka bentuk ini bersifat pragmatik dan menyediakan peluang kepada pelajar untuk menguji dan memberi pandangan kepada pereka bentuk bahan 
dalam menyiapkan bahan PdP bahasa yang berkualiti. Kajian reka bentuk ini melibatkan tiga fasa, iaitu (1) fasa analisis keperluan, (2) fasa reka bentuk dan pembangunan, dan (3) fasa pelaksanaan dan penilaian. Kertas ini hanya membincangkan semua tahap penilaian dalam fasa pembangunan bahan (fasa 2) dan fasa pelaksanaan dan penilaian (fasa 3) sahaja. Dalam fasa pembangunan, penilaian serta komen pakar, pensyarah, dan pelajar dianalisis, manakala dalam fasa pelaksanaan dan penilaian, kajian rintis dan kajian lapangan dilaksanakan.

Dalam fasa pembangunan, kandungan, aspek pedagogi dan reka bentuk bahan dinilai, manakala dalam fasa pelaksanaan dan penilaian, aspek kebolehlaksanaan dan kekuatan bahan ini dinilai. Rajah 3 menunjukkan fasa pembangunan bahan dan proses penilaian formatif yang dijalankan.

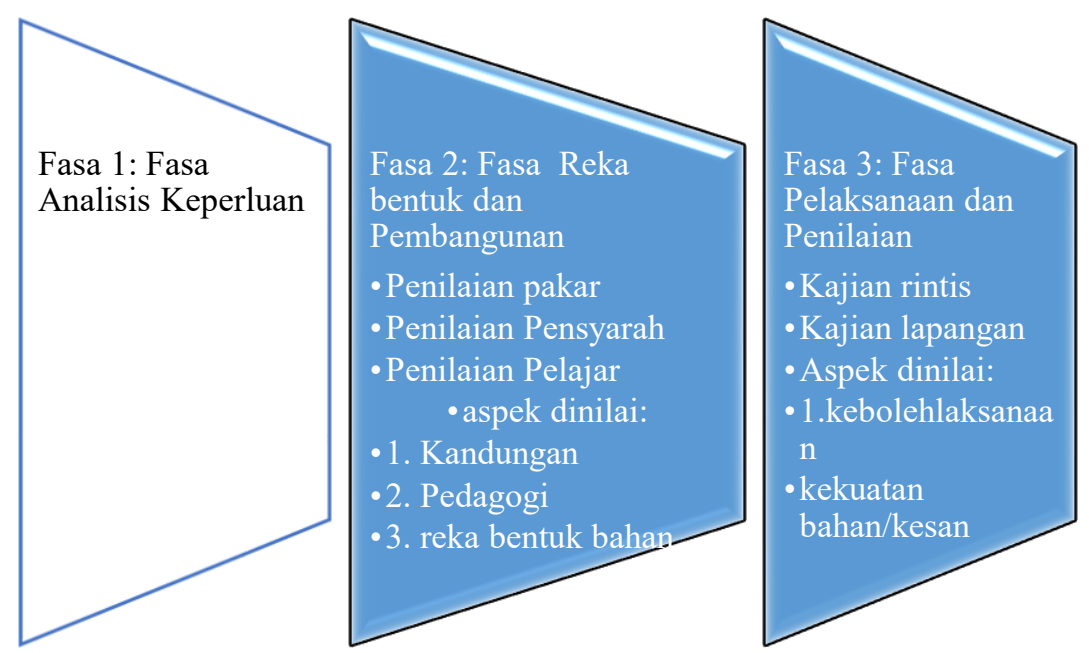

Rajah 3: Fasa pembangunan bahan pengajaran dan pembelajaran dan proses penilaian yang dilaksnanakan (Diadaptasi dari Dick, Carey dan Carey, 2005)

\section{Responden Kajian}

Fasa penilaian formatif dalam kajian ini melibatkan fasa dua dan tiga sahaja. Responden yang terlibat dalam fasa dua ialah pakar bidang, pensyarah dan pelajar, manakala dalam fasa tiga, hanya pensyarah dan pelajar sahaja dilibatkan.

Dalam fasa 2, pakar yang terlibat terdiri daripada dua orang pakar pedagogi dari Universiti Pendidikan Sultan Idris dan empat orang pensyarah bahasa Melayu dari tiga universiti di Thailand, iaitu Thaksin University, Princes of Songkhla Universiti dan Yala Rajabhat University, manakala pelajar dari Songkhla Rajabhat University dipilih sebagai responden kajian dalam fasa ini. Responden pelajar ini dipilih kerana mempunyai persamaan dengan responden sasaran dari aspek yang berikut, iaitu mereka sedang mempelajari kursus dan latar belakang yang hampir sama dengan pelajar di Universiti Thaksin.

Pakar dan pensyarah yang dipilih akan menilai kesesuaian bahan PdP dari aspek kandungan, bahan pembelajaran dan aspek pedagogi. Jadual 1 menunjukkan taburan panel penilai yang dilibatkan dalam fasa penilaian formatif.

Jadual 1. Senarai Panel Penilai Bahan PdP

\begin{tabular}{lllcl}
\hline Penilai & Kapasiti & Kelulusan & $\begin{array}{c}\text { Pengalaman } \\
\text { mengajar }\end{array}$ & Tempat bertugas \\
\hline P 1 & Pakar & Ph.D & 20 & Universiti Pendidikan Sultan Idris \\
P 2 & Pakar & Sarjana & 18 & Universiti Pendidikan Sultan Idris \\
A & Pensyarah & Sarjana & 25 & Universiti Thaksin
\end{tabular}




\begin{tabular}{lllcl} 
B & $\begin{array}{l}\text { Pensyarah } \\
\text { (undangan) }\end{array}$ & Ph.D & 15 & Princes of Songkhla University \\
C & Pensyarah & Ph.D & 20 & Princes of Songkhla University \\
D & Pensyarah & Sarjana & 7 & Yala Rajabhat Universiti \\
\hline
\end{tabular}

Dalam fasa terakhir, pelajar kursus Bahasa Melayu Elektif dari Universiti Thaksin dilibatkan sebagai responden. Mereka terdiri daripada pelajar yang mewakili pelbagai peringkat dan jurusan. Fasa ini dijalankan bagi mendapatkan pandangan pensyarah dan pelajar terhadap kebolehlaksanaan bahan yang dibangunkan berteraskan pendekatan pengajaran bahasa secara kontekstual dalam kajian lapangan.

Jadual 2. Responden Mengikuti Fasa

\begin{tabular}{lccc}
\hline Responden & $\begin{array}{l}\text { Fasa 1: Analisis } \\
\text { Keperluan Pelajar }\end{array}$ & $\begin{array}{l}\text { Fasa 2: Reka bentuk } \\
\text { dan Pembangunan } \\
\text { Bahan PdP }\end{array}$ & $\begin{array}{l}\text { Fasa 3: Pelaksanaan } \\
\text { dan Penilaian Bahan } \\
\text { PdP }\end{array}$ \\
\hline Pelajar & $\sqrt{ }$ & $\sqrt{ }$ & $\sqrt{ }$ \\
Pensyarah & & $\sqrt{ }$ & \\
Pakar & & $\sqrt{ }$ & \\
\hline
\end{tabular}

\section{INSTRUMEN KAJIAN}

Dua jenis instrumen yang digunakan dalam kajian ini, iaitu borang penilaian bahan PdP dan komen bersemuka. Borang Penilaian bahan PdP pensyarah dibina bagi menilai item-item berikut, iaitu (i) kesesuaian objektif dengan aktiviti yang dirancang, (ii) kesesuaian aktiviti pengajaran dan pembelajaran yang digunakan, (iii) kesesuaian peringkatan aktiviti daripada senang ke susah, (iv) kesesuaian pemilihan bahan mengajar, (v) kemampuan pelajar mengikuti bahan PdP yang dibangunkan, (vi) kesesuaian aras bahasa yang digunakan dalam bahan PdP ini, dan (vii) kesesuaian latihan tatabahasa berdasarkan konteks. Borang penilaian bahan PdP pelajar pula digunakan bagi menilai kesesuaian bahan PdP dari aspek dengan ilustrasi, teknikal, kesukaran bahasa, tahap dan kebolehan.

Instrumen kedua pula ialah komen bersemuka pensyarah dan pelajar. Komen bersemuka dijalankan secara langsung terhadap bahan PdP yang dibangunkan. Jadual 3 menunjukkan instrumen yang digunakan dalam kajian ini.

Jadual 3. Instrumen Kajian Mengikuti Fasa

\begin{tabular}{ll}
\hline Instrumen & Fasa \\
\hline Borang penilaian kesesuaian bahan PdP (Pensyarah/Pakar) & F 2 \\
$\begin{array}{l}\text { Borang penilaian kebolehlaksanaan bahan PdP (Pelajar) } \\
\text { Komen bersemuka (Pensyarah) }\end{array}$ & F 3 \\
Komen bersemuka (Pelajar) & F 3 \\
\hline
\end{tabular}

\section{Cara Pengumpulan Data}

Proses mendapatkan data penilaian bahan dimulakan dengan menentukan panel penilai dalam bidang yang ditetapkan, iaitu bidang kandungan, bahan PdP dan pedagogi. Setelah dipilih berdasarkan kriteria yang ditetapkan, surat lantikan rasmi dihantar kepada responden pakar, selain dihubung melalui emel dan telefon. Borang penilaian bahan PdP bahasa berserta bahan PdP bahasa yang telah dibangunkan, diserahkan kepada panel penilai. Komen dan cadangan mereka digunakan sebagai panduan untuk penambahbaikan bahan PdP bahasa dari pelbagai aspek. 
Dalam penilaian kajian rintis dan kajian sebenar pula, pengkaji menghantar surat lantikan dan meminta kebenaran daripada pihak universiti untuk menentukan tarikh bagi menjalankan kajian. Seterusnya, bahan PdP dan borang penilaian bahan PdP diserah kepada responden kajian. Akhirnya, pengkaji mengumpul semua bahan PdP dan borang penilaian untuk menganalisis data.

\section{Cara Penganalisisan Data}

Penilaian pakar dianalisis berdasarkan dua cara, iaitu (i) skor dan (ii) pandangan dan cadangan penilai. Skor dikira mengikuti Likert 5 tahap, iaitu (i) $5=$ sangat baik, (ii) $4=$ baik, (iii) $3=$ sederhana, (iv) $2=$ lemah, dan (v) 1 = sangat lemah.

Bagi menganalisis pandangan pakar, borang penilaian bahan PdP digunakan. Daripada pandangan dan komen pakar, pensyarah, dan pelajar, pengkaji akan mendapatkan gambaran tentang apa-apa yang perlu baiki dalam kajian ini untuk membentuk bahan PdP yang lebih berkualiti dan kreatif. Selain itu, pandangan dan cadangan pakar/pensyarah dan pelajar dicatat dan dikumpulkan berdasarkan tema yang ditentukan dalam borang penilaian bahan PdP. Tegasnya, Tessmer (1993) menyatakan bahawa setiap maklumat yang diperoleh daripada pakar, dicatat dalam borang pandangan pakar bagi memastikan semua soalan yang dirancang dikemukakan kepada pakar, serta semua komen daripada pakar dicatat bagi tujuan melakukan semakan dan penambahbaikan. Contoh komen yang diperoleh daripada pakar adalah seperti dinyatakan dalam jadual di bawah.

Jadual 4. Komen dan Pandangan Pakar Secara Keseluruhan terhadap Kandungan Bahan PdP KBME

\begin{tabular}{|c|c|c|c|c|}
\hline \multirow[b]{2}{*}{ Komponen } & \multicolumn{2}{|c|}{ Pakar 1} & \multicolumn{2}{|c|}{ Pakar 2} \\
\hline & Skor & Pandangan & Skor & Pandangan \\
\hline $\begin{array}{l}\text { 1. Kesesuaian objektif dengan } \\
\text { aktiviti yang dirancang }\end{array}$ & 4 & Sesuai. & 5 & $\begin{array}{l}\text { Objektif sesuai dengan aktiviti } \\
\text { yang dirancang. }\end{array}$ \\
\hline $\begin{array}{l}\text { 2. Kesesuaian aktiviti pengajaran } \\
\text { dan pembelajaran yang digunakan }\end{array}$ & 5 & Sesuai & 4 & $\begin{array}{l}\text { Ada beberapa aktiviti dalam } \\
\text { bahan perlu disesuaikan. }\end{array}$ \\
\hline $\begin{array}{l}\text { 3. Kesesuaian peringkatan aktiviti } \\
\text { daripada senang ke susah }\end{array}$ & 4 & Ada peringkatan. & 4 & $\begin{array}{l}\text { Peringkatan aktiviti dalam bahan } \\
\text { PdP bahasa tertentu perlu disusun } \\
\text { semula utuk memudahkan pelajar } \\
\text { melaksanakan aktiviti. }\end{array}$ \\
\hline $\begin{array}{l}\text { 4. Kesesuaian pemilihan bahan } \\
\text { mengajar }\end{array}$ & 5 & $\begin{array}{l}\text { Sesuai dengan bahan } \\
\text { pengajaran. }\end{array}$ & 4 & $\begin{array}{l}\text { Bahan dan grafik perlu } \\
\text { diperbaiki. }\end{array}$ \\
\hline $\begin{array}{l}\text { 5. Kemampuan pelajar mengikuti } \\
\text { bahan PdP bahasa yang } \\
\text { dibangunkan }\end{array}$ & 4 & $\begin{array}{l}\text { Tiada masalah yang } \\
\text { serius }\end{array}$ & 5 & $\begin{array}{l}\text { Dijangka pelajar dapat mengikuti } \\
\text { bahan PdP bahasa yang } \\
\text { disediakan. }\end{array}$ \\
\hline $\begin{array}{l}\text { 6. Kesuaian aras bahasa yang } \\
\text { digunakan dalam bahan PdP } \\
\text { bahasa ini }\end{array}$ & 4 & Perlu dibaiki. & 5 & Sesuai. \\
\hline $\begin{array}{l}\text { 7. Kesesuaian latihan tatabahasa } \\
\text { berdasarkan konteks }\end{array}$ & 4 & Relevan. & 5 & $\begin{array}{l}\text { Sesuai. Beberapa kosa kata dalam } \\
\text { aktiviti kebahasaan perlu diubah. }\end{array}$ \\
\hline Komen-komen lain yang relevan & $\begin{array}{l}\text { 1. Ela } \\
\text { bahas } \\
\text { pengg } \\
\text { 2. No } \\
\text { dimak } \\
\text { dilam }\end{array}$ & $\begin{array}{l}\text { an penggunaan } \\
\text { bunda dalam } \\
\text { laan bahasa Melayu } \\
\text { nota yang } \\
\text { idkan tidak } \\
\text { rkan. }\end{array}$ & $\begin{array}{l}\text { Perse } \\
\text { teknil } \\
\text { disest } \\
\text { meng } \\
\text { baik. }\end{array}$ & $\begin{array}{l}\text { bahan bahan PdP bahasa dari aspek } \\
\text { l, teks, dan grafik diharap dapat } \\
\text { ikan dengan keperluan } \\
\text { silkan bahan PdP bahasa yang }\end{array}$ \\
\hline Min & 4.8 & & 4.57 & \\
\hline
\end{tabular}




\section{DAPATAN KAJIAN}

Dapatan kajian akan dibincangkan bagi menjawab objektif-objektif kajian yang ditetapkan.

Objektif 1: "Mengenal pasti penilaian pakar dan pensyarah dari aspek kesesuaian bahan pengajaran dan pembelajaran Bahasa Melayu yang dibangunkan dalam fasa reka bentuk dan pembangunan”

Jadual 6. Penilaian Pakar terhadap Kesesuaian Bahan PdP secara Keseluruhan Berdasarkan Skor Min

\begin{tabular}{llll}
\hline Penilai & Skor & Min & Tahap \\
\hline Pakar 1 (P1) & 30 & 4.28 & Baik \\
Pakar 2 (P2) & 32 & 4.57 & Baik \\
\hline Keseluruhan & 62 & 4.43 & Baik \\
\hline
\end{tabular}

Berdasarkan jadual 6, jelas bahawa secara keseluruhannya tahap kesesuaian bahan PdP ini adalah pada tahap yang baik, iaitu pada skor min 4.43. Hal ini menunjukkan bahawa bahan PdP ini perlu dibaiki untuk lebih berkualiti.

Jadual 7 . Penilaian Pensyarah terhadap Kesesuaian Bahan PdP bahasa secara Keseluruhan Berdasarkan Skor Min

\begin{tabular}{llll}
\hline Penilai & Skor & Min & Tahap \\
\hline A & 27 & 3.85 & Sederhana \\
B & 34 & 4.86 & Baik \\
C & 24 & 3.43 & Sederhana \\
D & 24 & 3.43 & Sederhana \\
\hline Keseluluhan & 109 & 3.89 & Sederhana \\
\hline
\end{tabular}

Jadual 7 pula menunjukkan penilaian pensyarah terhadap kesesuaian bahan PdP secara Keseluruhan. Berdasarkan Jadual 7 jelas bahawa secara keseluruhannya, tahap kesesuaian bahan PdP ini ialah pada paras sederhana, iaitu pada skor min 3.49. Hal ini menunjukkan bahawa bahan PdP ini perlu diperbaiki bagi memantapkannya.

Objektif 2: "Mengenal pasti penilaian pelajar terhadap bahan pengajaran dan pembelajaran Bahasa Melayu yang dibangunkan dalam fasa reka bentuk dan pembangunan”

Bahagian ini akan mengemukakan komen responden pelajar terhadap bahan PdP dari aspek warna, bahan, aktiviti dan aras kesukaran.

\section{(i) Warna}

Dalam proses pembangunan bahan $\mathrm{PdP}$, warna memainkan peranan yang penting dalam proses pembelajaran. Hal ini demikian kerana warna dapat menarik perhatian dan minat pelajar terhadap pembelajaran. Dapatan kajian menunjukkan bahawa warna yang digunakan dalam bahan PdP sesuai dan cantik serta dapat menarik perhatian dan minat pelajar. Antara komen pelajar tentang hal ini ialah:

“warna yang digunakan dalam bahan PdP ini sangat cantik dan sesuai dengan penglihatan” (P073, T17/07/17) 
Responden pelajar juga menyatakan bahawa warna yang digunakan dalam bahan PdP dapat meningkatkan minat mereka terhadap pembelajaran bahasa. Antara komennya ialah:

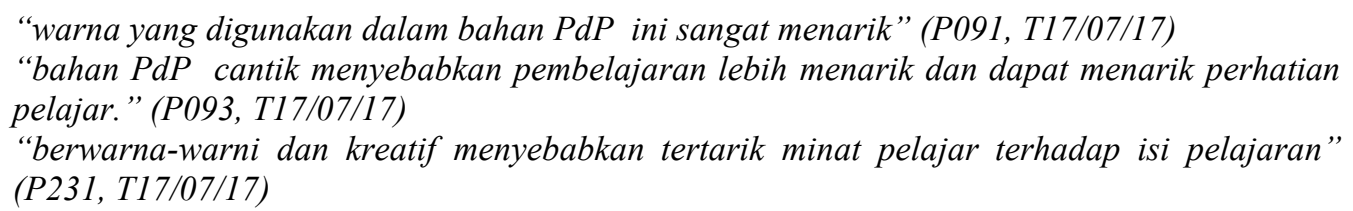

Seterusnya, warna yang digunakan dalam bahan PdP dapat membantu pelajar memahami proses PdP. Komennya:

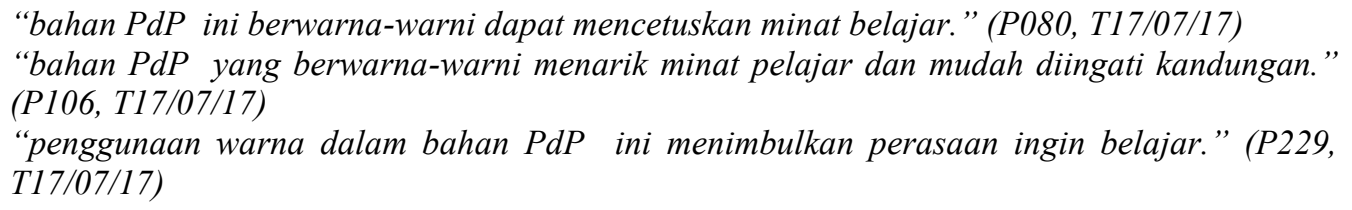

Kesimpulan, responden bersependapat bahawa warna yang digunakan setiap aktiviti dalam bahan PdP sesuai dan dapat mendorong pelajar kepada pembelajaran berdasarkan komen-komen responden yang dijelaskan.

\section{(ii) Bahan}

Pelbagai bahan seperti bahan media, bahan visual, dan petikan digunakan dalam proses PdP bahasa Melayu ini. Dapatan kajian mendapati bahan-bahan ini dapat meningkatkan kemahiran bahasa dalam kalangan pelajar. Antara pandangan yang diberi oleh pelajar ialah:

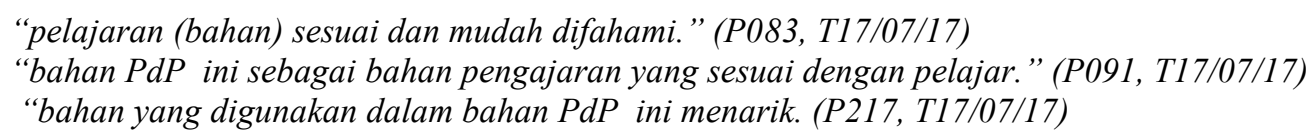

Seterusnya, responden pelajar berpendapat pemilihan pelbagai bahan dalam bahan PdP dapat menjadikan proses PdP lebih hidup dan ceria. Antara komen mereka ialah:

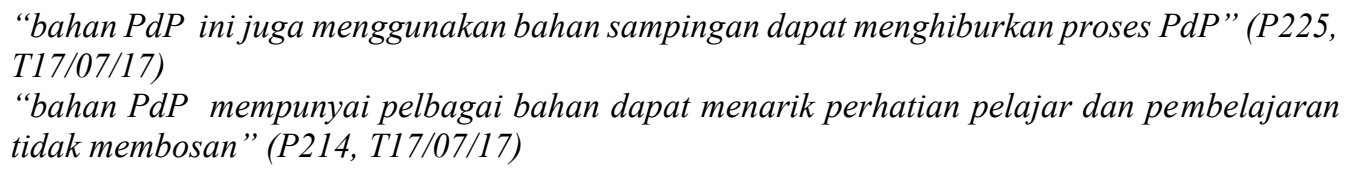

Selain itu, bahan media yang digunakan dalam bahan PdP ini sejajar dengan era teknologi, seperti yang dijelaskan oleh pelajar: Antara komen mereka:

“Dalam bahan PdP juga terdapat penggunaan teknologi (bahan media)” (P230, T17/07/17)

\section{(iii) Aktiviti}

Bahan PdP ini mengandungi aktiviti yang pelbagai seperti permainan bahasa, aktiviti mendengar, aktiviti komunikasi, aktiviti membaca dan aktiviti menulis. Aktiviti yang terdapat dalam bahan PdP ini banyak dan pelbagai. Antara komen responden pelajar terhadap kepelbagaian aktiviti ialah:

"bahan PdP ini terkandung pelbagai dan menyeronokkan suasana bilik darjah.” (P230, T17/07/17) 
Sehubungan dengan itu, kepelbagaian aktiviti juga memberi kesan yang positif dalam pembelajaran. Komen mereka:

\section{"Pelbagai aktiviti dalam bahan PdP ini menyebabkan tertarik minat pelajar terhadap pembelajaran." (P086, T17/07/17)}

Bahan PdP ini juga menyediakan pelbagai aktiviti untuk meningkatkan kemahiran bahasa dalam kalangan pelajar. Hal ini menunjukkan bahawa aktiviti yang dilaksanakan dapat membantu proses PdP dan tercapainya objektif yang ditentukan dalam setiap aktiviti dalam bahan PdP ini. Yang berikut ialah komen pelajar tentang hal ini:

"Setiap aktiviti mempunyai objektif masing-masing, dan dapat mencapai objektif yang ditetapkan serta dapat meningkatkan semua kemahiran bahasa (mendengar, bertutur, membaca dan menulis)." (P106, T17/07/17)

\section{(v) Aras Kesukaran}

Menurut responden pelajar, isi kandungnan bahan PdP ini dibangunkan berdasarkan aras kesukaran yang sesuai dengan kemampuan pelajar. Namun, terdapat juga aktiviti yang sukar dilaksanakan. Antara komen mereka ialah:

“Aktiviti boleh dijalankan...” (P214, T17/07/17)

"Terdapat juga aktiviti yang tidak faham dan sukar bagi pelajar yang tidak memiliki asas dalam bahasa Melayu." (P116, T17/07/17)

\section{Objektif 3: "Mengenal pasti penilaian pensyarah dan pelajar dalam fasa kajian rintis atau fasa kebolehlaksanaan”}

Penilaian Pensyarah:

Dari aspek kandungan, pensyarah menyatakan bahawa isi kandungan yang disampaikan dalam bahan PdP yang dibangunkan boleh difahami oleh pelajar kerana istilah, ayat serta teks yang digunakan sesuai dengan kemampuan pelajar. Selain itu, penggunaan bahasa dalam bahan PdP bahasa ini jelas dan tidak mengelirukan pelajar. Beliau juga menyatakan bahawa aspek kandungan bahan PdP ini boleh diterima dan tidak perlu diuah suai.

Dari aspek bahan pengajaran pula, beliau menjelaskan bahawa aktiviti dalam setiap bahan PdP itu terlalu banyak. Namun, bahan dan aktiviti tersebut masih boleh diikuti oleh pelajar. Dari aspek kesalahan bahasa pula, tidak terdapat kesalahan ejaan yang ketara dalam bahan ini.

Secara keseluruhannya, dari aspek teknikal, warna, pemilihan jenis dan saiz fon, dan ilustrasi yang digunakan dalam bahan PdP ini dapat menyokong proses pengajaran dan pembelajaran.

Dari aspek pedagogi, pensyarah menyatakan bahawa strategi pengajaran yang digunakan dalam bahan PdP ini boleh dilaksanakan dalam bilik darjah. Beliau juga menyatakan bahawa pelajar boleh mengikuti semua bahan dan aktiviti yang dilaksanakan dalam setiap bahan. Beliau turut menyatakan bahawa bahan PdP ini dapat membantu pelajar memahami teks dan bahan lisan serta meningkatkan kemahiran interpersonal dan presentasi pelajar.

Dari aspek kemahiran bahasa, beliau menyatakan bahawa bahan PdP ini dapat meningkatkan kemahiran bahasa seperti kemahiran lisan, membaca, menulis dan penguasaan kosa kata. Beliau juga menyatakan bahawa aktiviti yang disediakan dalam setiap bahan PdP dapat mencapai objektif yang ditetapkan dan dapat meningkatkan kemahiran berbahasa mereka.

Dari aspek penilaian, beliau menyatakan bahawa latihan yang disediakan dapat mencapai objektif pelajaran dan dapat menguji penguasaan kemahiran bahasa pelajar seperti kemahiran lisan, membaca, menulis dan 
penguasaan kosa kata. Latihan yang disediakan selaras dan meliputi semua kandungan pelajaran. Selain itu, soalan yang digunakan dalam setiap latihan dan aktiviti jelas dan mudah difahami oleh pelajar. Penilaian yang digunakan dalam bahan PdP ini juga dapat mencapai objektif pelajaran.

Secara keseluruhan, beliau menyatakan bahawa bahan PdP bahasa Melayu ini sesuai dengan kemampuan pelajar asing, walaupun terdapat beberapa kelemahan. Bahan PdP bahasa ini dijangka dapat meningkatkan keempat-empat kemahiran berbahasa, termasuk penguasaan kosa kata dalam kalangan pelajar. Selain itu, bahan ini dapat mendorong pelajar untuk meminati PdP Bahasa Melayu.

Penilaian Pelajar:

Dari aspek kandungan, pelajar menyatakan bahawa masa yang diperuntukkan bagi menjalankan aktiviti sesuai dan dapat mencapai objektif. Komen mereka:

$$
\begin{gathered}
\text { "Masa yang disediakan sudah sesuai..." (P20, BP10/03/17) } \\
\text { “...Pelajar boleh mengikuti aktiviti dalam masa yang ditetapkan." (P7, BP10/03/17) } \\
\text { "Masa yang digunakan dapat mencapai objektif." (P3, BP10/03/17) }
\end{gathered}
$$

Selain itu, pelajar 1 dan 3 (P1\& P3 BP10/03/17) turut menyatakan bahawa kandungan dalam bahan ini perlu dibaiki kerana terdapat pelajar tidak dapat memahami kandungan bahan PdP bahasa ini. Hal ini bertentangan dengan pandangan pensyarah menyatakan bahawa kandungan sesuai dengan tahap kemampuan pelajar serta dapat meningkatkan kemahiran berbahasa dalam kalangan mereka.

Sehubungan itu, majoriti pelajar juga menyatakan bahawa pengajaran menggunakan bahan PdP bahasa boleh dijalankan dalam masa yang ditetapkan dan kandungannya dapat meningkatkan kemahiran berbahasa. Yang berikut adalah antara komen pelajar terhadap aspek kandungan:

\section{"Pengajaran menggunakan modul boleh dijalankan dalam masa yang ditetapkan." (P5\& P22,} BP10/03/17)

Seterusnya, semua pelajar menyatakan bahawa kandungan dalam bahan ini dapat meningkatkan kemahiran bahasa. Dalam hai ini pelajar P4 menyatakan bahawa:

"Ya, banyak bantu saya." (P4\& P13, BP10/03/17)

Dari aspek bahan pengajaran pula, majoriti pelajar menyatakan bahawa bahan pengajaran dan pembelajaran yang disediakan dapat diikuti dan mencapai objektif pelajaran. Walaupun terdapat beberapa orang pelajar menyatakan bahawa masih terdapat kelemahan dalam bahan ini. Namun, bahan ini dapat meningkatkan kemahiran bahasa mereka. Dari aspek aktiviti pula, pelajar menyatakan bahawa aspek ini perlu ditambah baik.

Malah, majoriti pelajar menyatakan bahawa aktiviti yang dilaksanakan mudah diikuti, khusus bagi pelajar yang berpengalaman dan pernah belajar bahasa Melayu. Yang berikut ialah komen mereka tentang hal ini:

"Aktiviti sudah sesuai dengan kemampuan pelajar." (P9, BP10/03/17)

“Aktiviti sudah sesuai." (P12\& P13\&P18\&P19\&P20, BP10/03/17)

Selain itu, pelajar juga mencadangkan bahan berwarna digunakan kerana bahan yang dicetak secara hitam putih adalah tidak jelas. Yang berikut ialah pandangan mereka tentang perkara ini:

“Gambar tidak jelas.” (P17, BP10/03/17)

Dari aspek pedagogi, semua pelajar menyatakan bahawa guru dapat menguruskan proses pengajaran dan pembelajaran yang terdapat dalam bahan PdP bahasa berdasarkan masa yang ditetapkan. Majoriti pelajar 
menyatakan bahawa mereka dapat mengikuti aktiviti dalam setiap bahan dan sesuai dengan tahap kemampuan mereka. Hanya sebilangan kecil sahaja menyatakan bahawa aktiviti yang dilaksanakan tidak sesuai dengan mereka kerana mereka tidak mempunyai kemahiran asas dalam bahasa Melayu. Mereka juga menyatakan bahawa bahan yang dibangunkan ini menarik dan menggalakkan mereka untuk mempelajari bahasa Melayu. Hal ini menunjukkan bahawa aspek pedagogi dalam bahan ini boleh dilaksanakan. Yang berikut ialah komen pelajar tentang hal ini:

"Guru dapat menguruskan masa dalam pengajaran menggunakan modul." (P2, BP10/03/17)

"Kebanyakan pelajar dapat mengikuti semua aktivti pengajaran dalam modul." (P3\&P9, BP10/03/17)

"Aktiviti dalam setiap modul sesuai dengan kemampuan saya, ada aktiviti yang mudah dan yang susah." (P9, BP10/03/17)

Dari aspek kemahiran bahasa, keseluruhan pelajar menjelaskan bahawa aktiviti dalam bahan ini dapat meningkatkan kemahiran lisan, membaca, menulis dan penguasaan kosa kata. Antara pandangan mereka:

"Saya dapat berlatih bahasa seperti berkomunikasi dengan kawan, dan presentasi ketika mempelajari bahasa Melayu dengan modul." (P1\&P9\&P12, BP10/03/17)

"Saya dapat mengetahui cara menyebut dengan betul dan rasa lebih cekap dalam serta banyak mengguna bahasa Melayu dengan kawan di dalam kelas." (P2\&P7\&P11\&P18\&P19, BP10/03/17)

"Saya dapat menulis kerana banyak menulis dalam aktiviti." (P9, BP10/03/17)

"Saya dapat lebih mengetahui penggunaan tanda baca dan tatabahasa." (P21, BP10/03/17)

"Saya dapat belajar dan menguasai kosa kata baru.” (P2\&P3\&P4\&P5\&P6 \&P18, $B P 10 / 03 / 17)$

Objektif 4: "Mengenal pasti penilaian dan pandangan pensyarah dan pelajar terhadap bahan yang dibangunkan dalam fasa kajian lapangan”

Yang berikut adalah antara pandangan responden pensyarah dan pelajar terhadap kemampuan bahan untuk meningkatkan kemahiran bahasa dan motivasi pelajar.

\section{Pandangan Pensyarah:}

Dari aspek kemahiran bahasa, responden pensyarah menyatakan bahawa bahan PdP ini dapat meningkatkan kemahiran berbahasa pelajar, khususnya kemahiran lisan, membaca, menulis dan penguasaan kosa kata. Aktiviti yang disediakan juga dapat membantu pelajar mencapai objektif yang ditentukan dan dapat meningkatkan kemahiran berbahasa mereka. Hal ini menunjukkan bahawa bahan PdP ini dapat meningkatkan kemahiran penting dalam kalangan pelajar.

Dari aspek motivasi, responden dalam kalangan pensyarah menyatakan bahawa aktiviti dalam bahan PdP ini dapat menarik perhatian, minat, keinginan belajar dan membangkitkan perasaan ingin belajar bahasa Melayu dalam kalangan pelajar. Bahan PdP ini juga menggalakkan pelajar belajar dengan lebih mudah dan aktif. Tegasnya, bahan PdP bahasa ini dapat memberi kesan positif terhadap proses PdP dalam kalangan pelajar.

\section{Pandangan Pelajar:}

Dari aspek kemahiran bahasa, keseluruhan responden pelajar menjelaskan bahawa aktiviti dalam bahan PdP ini dapat meningkatkan kemahiran lisan, membaca, menulis dan penguasaan kosa kata dengan baik. Responden pelajar (P083, P230, dan P283) menjelaskan bahawa bahan PdP ini dapat meningkatkan kemahiran lisan mereka. Responden pelajar (P106) juga menyatakan bahawa setiap bahan PdP bahasa ini mengandungi aktiviti yang menekankan kemahiran yang berlainan. Dari aspek kemahiran membaca, 
responden pelajar (P214) turut menyatakan bahawa bahan PdP ini juga menekankan kemahiran tersebut, khususnya dari aspek sebutan. Hal ini penting kerana sebutan menjadi asas kepada kemahiran bacaan yang lain.

Justeru, responden pelajar menyatakan bahawa aktiviti dan latihan yang disediakan dalam bahan PdP dapat meningkatkan kemahiran menulis (P208). Aktiviti penguasaan kosa kata baharu yang didedahkan dalam bahan PdP ini membantu pelajar membina ayat dengan betul (P229 dan P116), malah responden pelajar (P208) menyatakan bahawa dia dapat mempelajari kosa kata dengan mudah dan dapat mengingati kosa kata baharu kerana latihan membina ayat dalam bahan PdP ini sangat membantu.

Dapatan kajian ini menunjukkan bahawa aktiviti dalam bahan PdP ini dapat meningkatkan kemahiran bahasa seperti kemahiran lisan, membaca, menulis dan penguasaan kosa kata dalam kalangan pelajar melalui bahan PdP yang dibangunkan.

Dari aspek motivasi, majoriti responden pelajar menyatakan bahawa bahan PdP dapat menyumbang terhadap sikap positif mereka dalam proses PdP bahasa Melayu (P083 dan P230). Responden pelajar turut menjelaskan bahawa mereka menyukai proses PdP dalam bahan PdP ini kerana aspek teknikal dan isi kandungannya sesuai dan menarik (P214).

Seterusnya, responden pelajar menjelaskan bahawa aktiviti dalam bahan PdP ini dapat mengurangkan perasaan bosan ketika mempelajari bahasa Melayu kerana kepelbagaian aktiviti yang terkandung di dalam bahan PdP (P208). Responden pelajar (P283) juga menyatakan bahawa aktiviti kemahiran mendengar (menonton VDO) menyebabkan proses PdP lebih seronok dan aktif.

Selain itu, pelajar (P083) menjelaskan bahawa cara persembahan dan susunan isi kandungan membantu mereka dalam penguasaan bahasa Melayu dengan lebih mudah dan senang. Responden pelajar (P225) juga menyatakan bahawa penggunaan ilustrasi dan warna yang menarik menyebabkan isi kandungan yang dipelajari mudah diingati dan senang diaplikasikan. Bahan PdP bahasa ini juga bermanfaat kepada pelajar kerana senang dipelajari, mudah difahami dan menarik (P106).

Kesimpulannya, bahan PdP ini dapat meningkatkan motivasi pelajar terhadap pembelajaran bahasa Melayu dalam kalangan pelajar Thai kerana sifat bahan PdP yang menarik dan relevan dengan pelajar, khususnya dari aspek isi kandungan, reka bentuk dan teknikal yang digunakan.

\section{PERBINCANGAN}

Pengajaran bahasa Melayu sebagai bahasa kedua dengan berbantukan bahan PdP yang menarik merupakan satu inovasi dalam pendidikan, khususnya dalam proses PdP bahasa Melayu di selatan Thailand. Athitaya Seangsuk, (2016) menyatakan bahawa penggunaan bahan PdP dalam proses PdP dapat membantu dan meningkatkan pencapaian pelajar. Hal ini demikian kerana pelajar dapat mempelajari bahan yang disediakan secara terancang dan teliti, melalui proses penilaian formatif yang terancang dan menyeluruh.

Farhana Idris dan Munirah Azrae (2015) juga mendapati bahawa penggunaan bahan PdP dapat meningkatkan pemahaman kandungan dalam kalangan pelajar dengan lebih cepat. Selain itu, Juwairiah Osman dan rakan-rakan (2018) menyatakan bahawa keberkesanan bahan dapat membantu pelajar antarabangsa untuk mempelajari bahasa Melayu dengan lebih berkesan. Oleh yang demikian dapat dirumuskan bahawa pembelajaran bahasa menggunakan bahan PdP KBME ini dapat memberi kesan yang positif dan mengurangkan tekanan terhadap pembelajaran.

Oleh yang demikian dapat disimpulkan bahawa proses pendekatan $C L I$ yang digunakan dalam bahan PdP ini dapat dilaksanakan dalam proses PdP bahasa Melayu. Hal ini demikian kerana prinsip CLI memberi kesan baik dan meningkatkan kemahiran bahasa dalam kalangan pelajar Thai, melalui penggunaan bahasa secara konteks dan aktiviti yang diaplikasikan dalam bahan PdP KBME. 


\section{KESIMPULAN}

Bahan pengajaran merupakan satu faktor bagi proses pengajaran dan pembelajaran lebih berkesan. Tenaga pengajar harus memilih bahan pengajaran yang sesuai dengan tahap kemampuan dan latar belakang pelajar, berkualiti, dan menarik perhatian, khususnya pelajar asing yang mempelajari bahasa sasaran dalam konteks negara sendiri. Bahan pengajaran amat penting dan dapat membantu proses PdP lebih berjaya. Oleh sebab itu, berdasarkan dapatan kajian di atas jelas bahawa pembangunan sesuatu bahan PdP perlulah mengambil kira semua pandangan pihak yang berkepentingan agar bahan yang dihasil nanti mempunyai kualiti dari aspek kandungan, bahan pengajaran dan pedagogi.

\section{RUJUKAN}

Ahmad Omar Chapakia (2002). Politik dan perjuangan masyarakat Islam di Selatan Thailand 1902-2002. Bangi: Penerbit Universiti Kebangsaan Malaysia.

Asmah Hj. Omar. (2003). Kaedah dan prinsip. Dlm Atiah Hj Mohd. Salleh \& Ramlah Muhamad (Pnyl). Pengajaran Bahasa Melayu untuk penutur asing (1-16). Kuala Lumpur: Dewan Bahasa dan Bahasa.

Awang Sariyan. (2012). Kemajuan Bahasa Melayu di perangkat kebangsaan dan antarabangsa: Cabaran dan pelan tindakan. Kuala Lumpur: Dewan Bahasa dan Pustaka.

Dick, W., Carey, L., \& Carey, J. O. (2005). The systematic design of instruction, (6th ed.). Boston: Allyn \& Bacon.

Farhana Idris \& Munirah Azrae (2015). Keberkesanan Pengajaran Bahasa Arab Untuk Pemahaman Ayat Al-Quran. E-Prosiding International Conference on Social Science Research (ICSSR 2015). ms. 890.

Islyas Mahyudin. (2008). Pembelajaran dan penelitan BMP di Thailand dan pemanfatan TIK. Kertas kerja dibentangkan Seminar Nasional Bahasa Pada Era Informasi (25-37). 28 Juni 2008. Medan: Gedung Prof. Ildrem USU.

Juwairiah Osman, Jamilah Bebe Mohamad, Anis Nabilla Ahmad, dan Jamal Rizal Razali. (2018). Strategi Pengajaran dan Pembelajaran Bahasa Melayu dalam Kalangan Pelajar Antarabangsa di Universiti Malaysia Pahang. Jurnal Pendeta, 9(1): 61-79.

Morrison, G. R., Ross, S. M., \& Kemp, J. E. (2007). Designing effective instruction, (5rd ed.). New York: John Wiley \& Sonc, Inc.

Pareeda Hayeeteh \& Suhaila Binsamaae.(2010). Learning and teaching Malay language in Islamic private school in Pattani province. Yala: Yala Rajabhat University.

Paitoon M. Chaiyanara. (2001). Hambatan struktur bahasa ibunda dalam pengajaran Bahasa Melayu bagi penutur Thai. Kertas Kerja dibentangkan di Seminar Antarabangsa Pengajaran Bahasa Melayu untuk Penutur Asing. Dalam Atilah Hj. Mohd. Salleh dan Ramlah Muhamad (penyelenggara). Pengajaran Bahasa Melayu Untuk penutur asing (136-155). Kuala Lumpur: Dewan Bahasa dan Pustaka.

Richey, R. C. \& Klien, J.D. (2007). Design and development reseach: Methods, strategies, and issue. Mahwah, NJ: Lawrence Erlbaum Associates Publisher.

Tessmer, M. (1993). Planning and conducting formative evaluations: improving the quality of education and training. London: Kogan Page Limited.

Worawit Baru (1999). Dasar kerajaan dan kesannya terhadap bahasa Melayu di negara Thai. Jabatan Pengajian Melayu, Fakulti Sastera dan Sains Sosial, Universiti Malaya.

Zulkifli Osman. (2013a). Kebolehlaksanaan dan Kebolehgunaan Modul Pengajaran Bahasa Berlandaskan Pendekatan Holistik. Jurnal Pendeta, 4(1): 202-230.

Zulkifli Osman. (2013b). Pembangunan modul pengajaran Bahasa Melayu secara bersepadu. Tesis doktor falsafah yang tidak diterbitkan. Universiti Malaya, Kuala Lumpur.

Zulkifli Osman. (2012). The Application of Holistic Approach in Teaching Language in Classroom : A Malay Language Context in Malaysia. Jurnal Isu Dalam Pendidikan, 35: 104-122. 